\title{
Effect of Citrus macroptera Fruit Pulp Juice on Alteration of Caspase Pathway Rendering Anti-Proliferative Activity against Ehrlich's Ascites Carcinoma in Mice
}

\author{
Md. Mahmudul Hasan ${ }^{1}$, Md. Shihabul Islam ${ }^{1}$, Kazi Md. Faisal Hoque ${ }^{1}$, Ariful Haque $^{2}$ and Md Abu Reza ${ }^{1}$ \\ ${ }^{1}$ Molecular Biology and Protein Science Laboratory, Department of Genetic Engineering and Biotechnology, Faculty \\ of Life and Earth Sciences, University of Rajshahi, Rajshahi, Bangladesh \\ ${ }^{2}$ Molecular Pathology Laboratory, Institute of Biological Sciences, University of Rajshahi, Rajshahi, Bangladesh
}

\begin{abstract}
Citrus macroptera (Rutaceae) has long been used in folk medicine in Bangladesh. Considering the folkloric context, this study was aimed to scrutinize anti-proliferative activity of $C$. macroptera fruit pulp juice (CMFPJ) against Ehrlich's ascites carcinoma (EAC). The anti-proliferative capacity of CMFPJ was investigated and confirmed primarily using MTT assay. In vivo anti-proliferative aptitude of CMFPJ was investigated with 25, 50, and $100 \mathrm{mg} / \mathrm{kg} /$ day intraperitoneal (i.p.) treatment. Anti-proliferative efficacy of CMFPJ was assessed based on EAC growth inhibition. CMFPJ inhibited EAC growth in vitro in a dose-dependent manner. And the percentages of in vivo EAC growth inhibition were $19.53,49.2$, and $68.9 \%$ at 25,50 , and $100 \mathrm{mg} / \mathrm{kg}$ CMFPJ respectively. CMFPJ significantly induced expression of apoptosis regulatory genes caspase-8, caspase-9, cytochrome-c, and caspase-3. This considerable anti-cancer activity was perhaps due to combinatorial effect of lectin, polyphenols, and flavonoids present in CMFPJ.
\end{abstract}

Key words: Citrus macroptera, Extrinsic pathway, Intrinsic pathway, Apoptosis

\section{INTRODUCTION}

Cancer is a disease in which constant clonal expansion of somatic cells kill by invading, subverting and eroding normal tissues (1). The treatment methods to fight against cancer comprise chemotherapy, radiotherapy, hormone therapy, and surgery (2); however, each of them has its own disadvantages and severely affects patient's normal cell. Therefore, the use of natural products nowadays has been contemplated of outstanding value in controlling

Correspondence to: Md Abu Reza, Molecular Biology and Protein Science Laboratory, Department of Genetic Engineering and Biotechnology, Faculty of Life and Earth Sciences, Sir Jagadish Chandra Bose Academic Building, 3rd Floor, University of Rajshahi, Rajshahi-6205, Rajshahi, Bangladesh

E-mail: reza.gen@ru.ac.bd

This is an Open-Access article distributed under the terms of the Creative Commons Attribution Non-Commercial License (http:// creativecommons.org/licenses/by-nc/3.0) which permits unrestricted non-commercial use, distribution, and reproduction in any medium, provided the original work is properly cited. cancer. Plant extracts can cause apoptosis through induction of caspase pathway (3). Apoptosis is a programmed cell death and a highly arranged manner to eradicate cancerous cells and plays a key role in tissue homeostasis and maintenance (4). Proteolytic enzymes such as caspases are central effector molecules in apoptosis and their activation or inactivation is vital in controlling cancer (5).

Citrus macroptera, also known as "wild orange" (6), is an indigenous fruit of Malaysia, Melanesia (7) and Bangladesh (8). C. macroptera is available in the hilly areas of north-eastern Bangladesh (Sylhet Division). Locally it is known as "Satkara" and has long been used to treat hypertension, stomach pain, alimentary disorders (9) and fever (10). C. macroptera fruit is significantly cytotoxic (11). The fruit pulp was reported to contain $2.89 \pm 0.32 \mathrm{mg}$ proteins and antioxidants including $291.06 \pm 10.14 \mathrm{mg}$ polyphenols, $145.02 \pm 0.36 \mathrm{mg}$ flavonoids, $526.08 \pm 3.32 \mathrm{mg}$ tannin, and $120.83 \pm 0.0019 \mathrm{mg}$ ascorbic acids per $100 \mathrm{~g}$ dry weight and significant radical scavenging activity was confirmed by an in vitro study (12). Epidemiological studies showed that many of these antioxidants possess anti- 
inflammatory, anti-atherosclerotic, anti-cancer, anti-mutagenic, anti-carcinogenic, anti-bacterial, and anti-viral activities (13). Considering the information mentioned above, this current study was undertaken to investigate the antiproliferative activity of $C$. macroptera fruit pulp juice (CMFPJ) against Ehrlich's ascites carcinoma (EAC) in mice.

\section{MATERIALS AND METHODS}

Chemicals and reagents. Dulbecco's modified Eagle's medium (DMEM) and 3-[4, 5-dimethylthiazol-2-yl]-2, 5diphenyltetrazolium bromide (MTT) were bought from Sigma-Aldrich (St. Louis, MO, USA). Hemagglutination buffer was prepared as $20 \mathrm{mM}$ Tris- $\mathrm{HCl}$ buffer, $\mathrm{pH} 7.8$ containing $1 \% \mathrm{NaCl}$ and $10 \mathrm{mM} \mathrm{CaCl} 2$. Trypan blue was bought from Invitrogen (Carlsbad, CA, USA). M-MLV (Moloney Murine Leukemia Virus) reverse-transcriptase was purchased from Tiangen (Beijing, China), primers were custom synthesized from IDT (Integrated DNA Technologies), Seri Kembangan, Selangor, Malaysia. GoTaq ${ }^{\circledR}$ qPCR Master Mix (2X) was collected from Promega (Madison, WI, USA). All other chemicals and reagents used were of analytical grade.

Plant sample. The fruits of $C$. macroptera were collected in mid-October, 2015 from a local market of Sylhet, Bangladesh. The collected fruits were authenticated by a taxonomist of the Department of Botany, University of Rajshahi (Rajshahi, Bangladesh); where a voucher specimen has been preserved under accession number 00212 for future reference.

Preparation of C. macroptera fruit pulp juice. The thick rind of $C$. macroptera fruit was removed by using a sharp knife with gloved hand to collect pulp. The pulp was cut into small pieces and juice was collected by squeezing the pieces of pulp with gloved hand. The juice was dried with VirTis BenchTop Pro Freeze Dryer (SP Scientific, Stone Ridge, NY, USA) and dissolved in distilled water at $1 \mathrm{~g} / 10 \mathrm{~mL}$ concentration. Juice was filtered by using Glass Fiber Filter paper (Macherey NAGEL GmBH, Düren, Germany) with DURAN ${ }^{\circledR}$ Filtering Apparatus (Mainz, Germany) at room temperature. Finally, the juice filtrate was again dried with VirTis BenchTop Pro Freeze Dryer and stored at $-20^{\circ} \mathrm{C}$ for further use.

Experimental animal and EAC cell. Male Swiss albino mice (25-30 g) were bought from the Department of Pharmacy of Jahangirnagar University (Dhaka, Bangladesh). The mice were housed in polypropylene cage (Tarson, Bangalore, India) and kept in the animal house of Institute of Biological Sciences (IBSc), University of Rajshahi under standard condition (12 hr light/dark cycle,
$25 \pm 2{ }^{\circ} \mathrm{C}$ temperature and $\sim 70 \%$ humidity). The animals were allowed to acclimatize for 1 week before beginning the experiment. Food and water were supplied ad libitum. Methodologies followed in this research work along with handling of experimental animal were approved by the Institutional Animal, Medical Ethics, Biosafety and Biosecurity Committee (IAMEBBC) for Experimentations on Animal, Human, Microbes and Living Natural Sources (license no: 31/320-IAMEBBC/IBSc), Institute of Biological Sciences (IBSc), University of Rajshahi. EAC cells used in this study were kindly provided by the Department of Pharmacy of Jahangirnagar University.

In vitro cytotoxicity test. In vitro cytotoxicity of CMFPJ was performed as described previously with a few modifications (14). Cytotoxicity of CMFPJ on the growth of EAC cell was determined by measuring the metabolic capacity using the 3-[4, 5-dimethylthiazol-2-yl]-2, 5diphenyltetrazolium bromide (MTT) assay. The MTT assay was carried out as follows: EAC cells $(100 \mu \mathrm{L}$ cells from $1 \times 10^{6}$ cells $/ \mathrm{mL}$ ) were treated for $24 \mathrm{hr}$ with five different doses of CMFPJ $(500,250,125,62.5$, and 31.25 $\mu \mathrm{g} / \mathrm{mL}$ in DMEM medium). After incubation at $37^{\circ} \mathrm{C}$ for $24 \mathrm{hr}, 0.1 \mathrm{mg}(50 \mu \mathrm{L}$ of a $2 \mathrm{mg} / \mathrm{mL}$ solution) MTT was added to each well and the cells were again incubated at $37^{\circ} \mathrm{C}$ for $8 \mathrm{hr}$. The aliquot was carefully removed and $100 \mu \mathrm{L}$ dimethylsulfoxide (DMSO) was then added to each well to dissolve the formazan crystal. The plate was read immediately at $540 \mathrm{~nm}$ on a multi-well plate reader (Multiskan $^{\mathrm{TM}}$ FC Microplate Photometer, Thermo Scientific, Waltham, MA, USA). All the experiments were performed in triplicate and the mean absorbance values were calculated. The results were articulated as the percentage of inhibition by comparing to the untreated control. The following equation was used to calculate the cell proliferation inhibition percentage:

$$
\begin{aligned}
& \text { Proliferation inhibition percentage }(\%) \\
& =\frac{(\mathrm{A}-\mathrm{B}) \times 100}{\mathrm{~A}}
\end{aligned}
$$

where $\mathrm{A}$ is the $\mathrm{OD}_{540 \mathrm{~nm}}$ of the cellular homogenate without CMFPJ (control) and $\mathrm{B}$ is the $\mathrm{OD}_{540 \mathrm{~nm}}$ of the cellular homogenate with CMFPJ.

Hemagglutination assay. To check the presence of lectin protein in CMFPJ, hemagglutination assay was performed with minor modification as described previously (15). A final volume of $100 \mu \mathrm{L}$ was prepared in 96-well flat-bottomed microtiter plate containing $50 \mu \mathrm{L}$ of CMFJ $(100 \mathrm{mg} / \mathrm{mL})$ serially diluted with $50 \mu \mathrm{L}$ hemagglutination buffer $(20 \mathrm{mM}$ Tris-HCl buffer, $\mathrm{pH} 7.8$ containing $1 \%$ $\mathrm{NaCl}$ and $10 \mathrm{mM} \mathrm{CaCl}_{2}$ ) and $50 \mu \mathrm{L}$ of $2 \%$ red blood cells (RBCs) suspension previously washed with $1 \% \mathrm{NaCl}$. PBS 
Table 1. Primers used for $P C R$ amplification

\begin{tabular}{|c|c|c|}
\hline Gene & Primer & Sequence \\
\hline \multirow[t]{2}{*}{ GAPDH } & Forward & 5'-GTGGAAGGACTCATGACCACAG-3' \\
\hline & Reverse & 5'-CTGGTGCTCAGTGTAGCCCAG-3' \\
\hline \multirow[t]{2}{*}{ Caspase- 8} & Forward & 5'-CTGCTGGGGATGGCCACTGTG-3' \\
\hline & Reverse & 5'-TCGCCTCGAGGACATCGCTCTC-3' \\
\hline \multirow{2}{*}{ Cytochrome-c } & Forward & 5'-CCAGGTATACAAGCAGGTGTGCTC-3' \\
\hline & Reverse & 5'-CATCATTAGGGCCATCCTGGAC-3' \\
\hline \multirow[t]{2}{*}{ Caspase-9 } & Forward & 5'-ATGGACGAAGCGGATCGG-3' \\
\hline & Reverse & 5'-CCCTGGCCTTATGATGTT-3' \\
\hline \multirow[t]{2}{*}{ Caspase-3 } & Forward & 5'-GCAGCAAACCTCAGGGAAAC-3' \\
\hline & Reverse & 5'-GGTTTCCCTGAGGTTTGCTG-3' \\
\hline
\end{tabular}

was used as a control. After a gentle shaking, the plate was set aside at room temperature for $30 \mathrm{~min}$. The visual agglutination titer of the maximum dilution giving the positive agglutination was noted.

EAC inoculation and treatment procedure. EAC cells $(200 \mu \mathrm{L})$ adjusted $10^{6}$ cells $/ \mathrm{mL}$ in saline water $(0.9 \%$ $\mathrm{NaCl})$ were pre-inoculated into the i.p. of mice on the $1 \mathrm{st}$ day (16). The mice were divided randomly into four groups $(\mathrm{n}=6)$. CMFPJ at 25,50 , and $100 \mathrm{mg} / \mathrm{kg} /$ day dosage was administrated to the treatment groups in a total volume of $200 \mu \mathrm{L}$ with distilled water for 7 consecutive days at a regular interval of $24 \mathrm{hr}$ starting from $24 \mathrm{hr}$ of post inoculation of EAC cells (17). Control mice received $200 \mu \mathrm{L}$ of saline solution each day.

In vivo cell growth inhibition assay. Cell growth inhibition assay was carried out as described previously $(16,18)$. After 7 consecutive days of treatment, $5 \mathrm{~mL}$ saline water $(0.9 \% \mathrm{NaCl})$ was injected into the peritoneum of mice of both control and treated groups and then they were anesthetized using chloroform. Then cells from peritoneum were harvested and diluted 10 times $(100 \mu \mathrm{L}$ : $900 \mu \mathrm{L})$ in saline. Thereafter, diluted cells were stained with Trypan blue dye for quantification of viable cells. Then $10 \mu \mathrm{L}$ cell suspension was placed on hemocytometer and viable cells were counted by using Optika inverted microscope (Italy). Cell growth inhibition percentage was calculated by the following formula:

Percentage $(\%)$ of cell growth inhibition

$$
=\left(1-\frac{\mathrm{T}}{\mathrm{C}}\right) \times 100
$$

where, $\mathrm{T}=$ mean number of EAC cells of CMFPJ treated group and $\mathrm{C}=$ mean number of EAC cells of control.

RNA isolation, reverse transcription and real timePCR. Total RNA from EAC of control and CMFPJ treated mice were isolated after $24 \mathrm{hr}$ of last treatment. RNA was extracted using RNAsimple Total RNA Kit (Tiangen, Bei- jing, China) according to the manufacturer's protocol. RNA quality was checked on $1 \%$ agarose gel stained with $10 \mu \mathrm{g} / \mathrm{mL}$ ethidium bromide and visualized via a gel documentation system (Alphaimager mini, New Taipei City, Taiwan). Concentration and purity of isolated RNA were measured by spectrometry at 260 and $280 \mathrm{~nm}$. Isolated RNA was then converted to cDNA using TIANscript MMLV reverse-transcriptase. For each reaction $(20 \mu \mathrm{L}), 1 \mu \mathrm{L}$ of $10 \mathrm{mM}$ oligo (dT), $1 \mu \mathrm{L}$ dNTPs (10 mM), $1 \mu \mathrm{g}$ RNA and nuclease-free water up to $15 \mu \mathrm{L}$ were taken in PCR tube and incubated at $70^{\circ} \mathrm{C}$ for $5 \mathrm{~min}$. The mixture was immediately chilled on ice for $3 \mathrm{~min}$. $1 \mu \mathrm{L}$ M-MLV reverse transcriptase, $4 \mu \mathrm{L}(5 \mathrm{X})$ of 1 st strand buffer was added to each tube and incubated at $45^{\circ} \mathrm{C}$ for $50 \mathrm{~min}$. Further, the mixture was incubated at $95^{\circ} \mathrm{C}$ for $5 \mathrm{~min}$ to inactivate the M-MLV reverse-transcriptase enzyme. Prepared cDNA was stored at $-20^{\circ} \mathrm{C}$ for further use. The reverse transcription products were used as templates for real-time PCR. PCR amplification was performed using specific primers (Table 1). Each reaction was performed in triplicate in $10 \mu \mathrm{L}$ volume containing $5 \mu \mathrm{L}$ GoTaq $^{\circledR}$ qPCR Master Mix (2X) (Promega, Madison, WI, USA), $0.5 \mu \mathrm{L}(10 \mathrm{mM})$ of each primer, $3 \mu \mathrm{L}$ nuclease free water and $1 \mu \mathrm{L}$ template. Thermal cycling was performed for each gene on cDNA samples in 48 -well reaction plates by using the $\mathrm{Eco}^{\mathrm{TM}}$ RealTime PCR System (Illumina ${ }^{\circledR}$, San Diego, CA, USA). Realtime PCR was conducted with the following cycling conditions: $95^{\circ} \mathrm{C}$ for $10 \mathrm{~min}$, followed by 40 cycles of $95^{\circ} \mathrm{C}$ for $30 \mathrm{sec}, 50^{\circ} \mathrm{C}$ for $30 \mathrm{sec}$ and $72^{\circ} \mathrm{C}$ for $25 \mathrm{sec}$. PCR reaction specificity was confirmed by melt curve analysis at $95^{\circ} \mathrm{C}$ for $15 \mathrm{sec}, 60^{\circ} \mathrm{C}$ for $15 \mathrm{sec}, 95^{\circ} \mathrm{C}$ for $15 \mathrm{sec}$. The quantitation of gene expression was carried out using GAPDH as an endogenous control and relative to the calibrator sample using the $\Delta \Delta \mathrm{Cq}$ method.

Statistical analysis. Data presented as mean \pm SD (Standard Deviation) and graphs were prepared by using Microsoft Excel 2007 (Microsoft Corporation, Redmond, WA, USA). Analysis of variance (ANOVA) was performed using SPSS (IBM, version 16; SPSS Inc., Chicago, IL, 


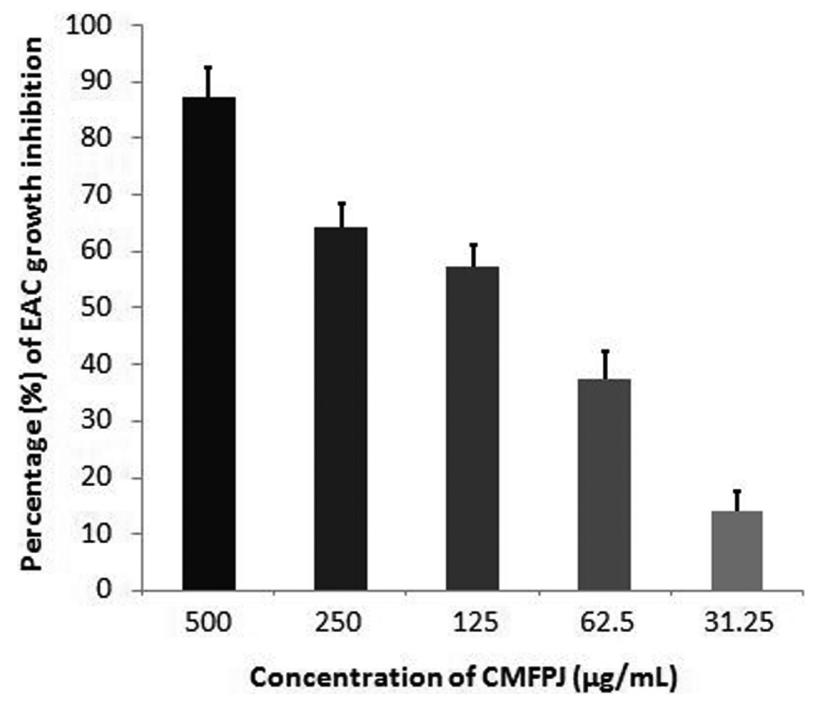

Fig. 1. Effect of CMFPJ on EAC growth in vitro. CMFPJ slowed down EAC cell growth in a dose-dependent manner. The results are represented as mean $\pm S D(n=3)$.

USA) and significance levels were checked at $p<0.05$, $p<0.01$, and $p<0.001$.

\section{RESULTS}

In vitro cytotoxicity test. The in vitro cytotoxic effect of CMFPJ on EAC cells was in a dose-dependent manner (Fig. 1). The CMFPJ inhibited $87.3 \%$ EAC cells at 500 $\mu \mathrm{g} / \mathrm{mL}$ concentration. The cytotoxic effect was in decreasing trend with the reduction of CMFPJ concentration and it reached to $13.9 \%$ at $31.25 \mu \mathrm{g} / \mathrm{mL}$.

Hemagglutination assay. Result regarding the hemagglutination assay demonstrated that CMFPJ has considerable agglutination activity on mouse RBCs (Fig. 2). CMFPJ showed hemagglutination activity on mouse RBCs

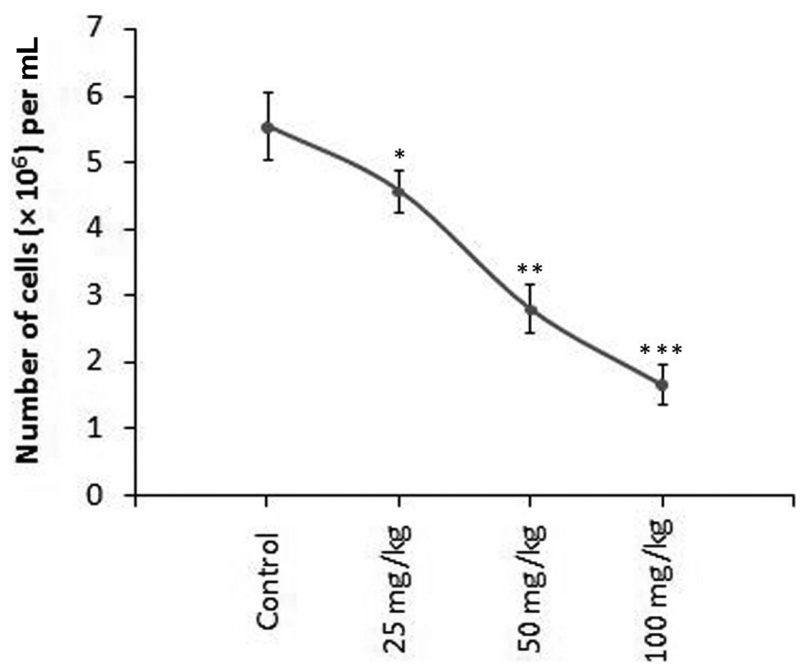

Fig. 3. In vivo effect of CMFPJ on EAC growth inhibition. CMFPJ significantly reduced EAC growth compared to control. Significance levels were determined and set at ${ }^{*} p<0.05,{ }^{*} p<$ 0.01 , and ${ }^{* * *} p<0.001$ in respect to the control. The results are represented as mean $\pm S D(n=6)$.

at the very last concentration of $39.06 \mu \mathrm{g} / 100 \mu \mathrm{L}$. Thereafter, the presence of lectin in CMFPJ was confirmed from the well-established agglutination activity on mouse RBCs.

In vivo cell growth inhibition assay. Result regarding cell growth inhibition revealed that CMFPJ significantly slowed down EAC growth in vivo in a dose-dependent manner (Fig. 3). The number of EAC counted in the control group were $5.53 \times 10^{6}$ cells $/ \mathrm{mL}$, whereas $4.45 \times 10^{6}$, $2.81 \times 10^{6}$, and $1.72 \times 10^{6} \mathrm{cells} / \mathrm{mL}$ were observed in the 25,50 , and $100 \mathrm{mg} / \mathrm{kg}$ CMFPJ treated group respectively (Fig. 3). According to the number of EAC cells, we found that CMFPJ reduced growth of EAC cells by $19.53,49.2$, and $68.9 \%$ at 25,50 , and $100 \mathrm{mg} / \mathrm{kg}$ CMFPJ respectively.

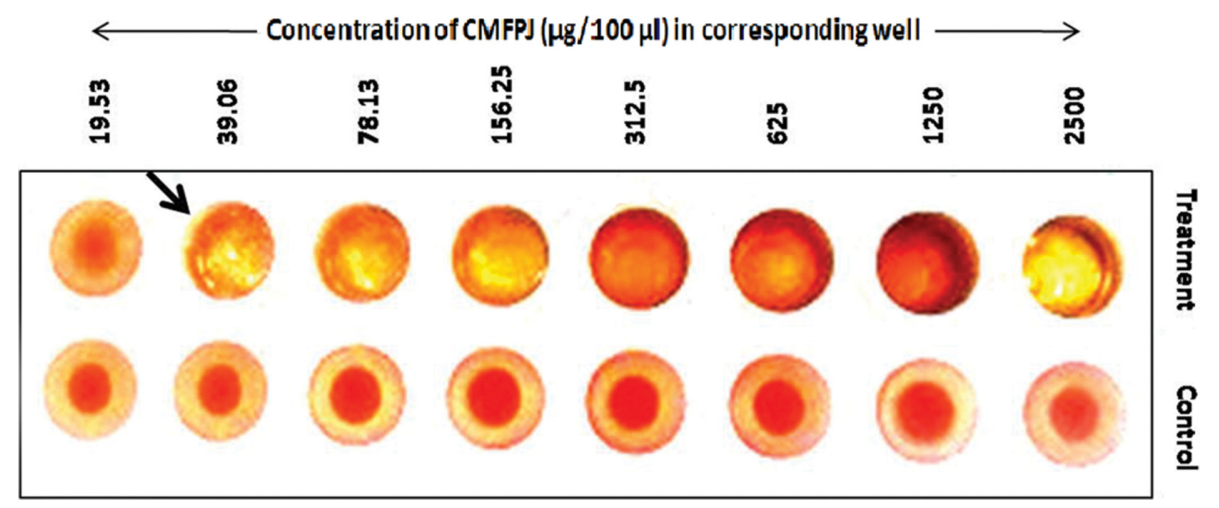

Fig. 2. Hemagglutination activity of CMFPJ. CMFPJ showed hemagglutination activity on mouse RBCs (upper row) but the control wells did not show hemagglutination at any concentration of PBS (lower row). 
(A)

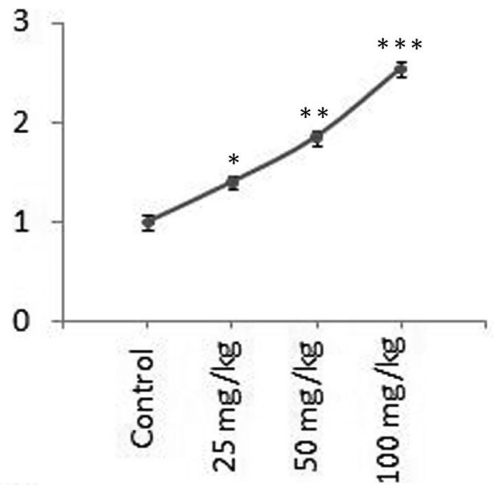

(C)

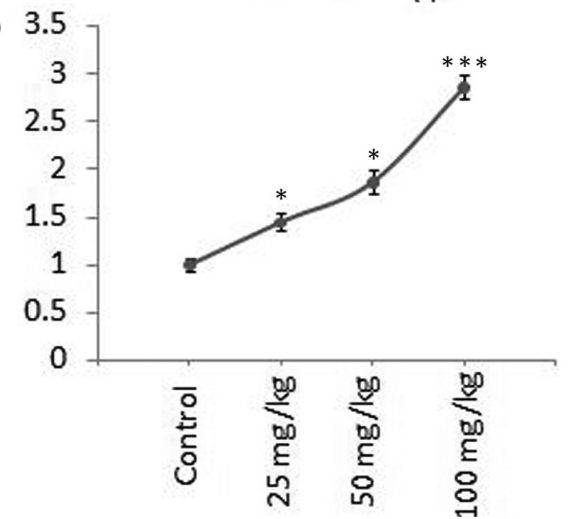

(B)

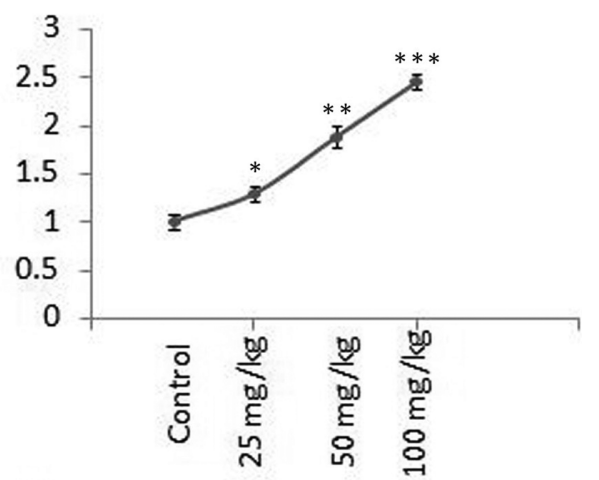

(D)

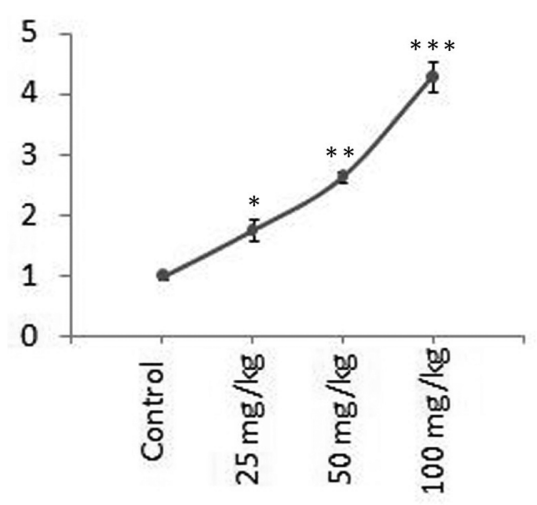

Fig. 4. Effect of CMFPJ on expression of apoptotic markers (A) caspase-8, (B) cytochrome-c, (C) caspase-9, and (D) caspase-3 in EAC. CMFPJ significantly increased the expression of caspase-8, cytochrome-c, caspase- 9 , and caspase-3 compared to control. Significance levels were determined and set at ${ }^{*} p<0.05$, ${ }^{* *} p<0.01$, and ${ }^{* * *} p<0.001$. The results are represented as mean \pm SD $(\mathrm{n}=3)$.

Real time-PCR. Molecular investigation demonstrated significant alteration in the expression of apoptosis regulatory genes caspase- 8 , cytochrome-c, caspase-9, and caspase3 in EAC grown in all CMFPJ treated groups (Fig. 4). The expression of the genes was in rising trend with the increasing amount of CMFPJ. CMFPJ increased the expression of caspase- 8 in a dose-dependent manner by $1.42,1.79$, and 2.58 fold with 25,50 , and $100 \mathrm{mg} / \mathrm{kg}$, respectively (Fig. 4). As shown in Fig. 4, at 25, 50, and $100 \mathrm{mg} / \mathrm{kg}$ dose of CMFPJ increased expression of cytochrome-c by $1.29,1.90$, and 2.49 fold respectively. The expression of caspase- 9 was amplified by $1.45,1.83$, and 2.87 fold at 25,50 , and $100 \mathrm{mg} / \mathrm{kg}$ CMFPJ respectively (Fig. 4). And the expression of caspase-3 was increased by $1.77,2.63$, and 4.21 fold at 25,50 , and $100 \mathrm{mg} / \mathrm{kg}$ CMFPJ respectively (Fig. 4).

\section{DISCUSSION}

Nowadays, phytochemicals are of greater interest in alternative cancer therapy from the points of less toxicity and cost benefit. The CMFPJ contained elevated amount of lectin, flavonoids, and polyphenols. However, in this study, we showed in vitro and in vivo cytotoxic activity of the CMFPJ in dose-dependent manner.

Lectins are ubiquitous protein with similar biochemical properties performing different functions and are profusely found in seeds and fruits pulp. Lectin was attached to the carbohydrate moieties on the surface of mouse erythrocytes and agglutinated them (19). The affinity of lectins towards cancer cell is higher than that of healthy cells (20). Thereafter, lectin exhibited EAC growth inhibition by altering cell cycle, inducing non-apoptotic G1phase accumulation mechanisms, G2/M phase cell cycle arrest, and apoptosis (21). According to a previous study, lectin from Pisum sativum seed reduced the EAC cell growth by 44 and $63 \%$ at $1.4 \mathrm{mg} / \mathrm{kg} /$ day and $2.8 \mathrm{mg} / \mathrm{kg} /$ day respectively (22).

Moreover, plants rich in polyphenols are known to be linked to decrease risk of developing cancer through various mechanisms, including apoptosis (23). The phenolic compound of CMFPJ induced oxidative stress on EAC, leading to cell cycle arrest and apoptosis (22). Besides, the flavonoids compacted cellular viability through activation of caspase mediated pathways (24). A similar study reported that fraction of Morus alba rich in polyphenols and flavonoids showed anti-proliferation of EAC by $70.20 \%$ at 100 $\mathrm{mg} / \mathrm{kg} /$ day (17). In our case, we found EAC growth inhi- 
bition by $19.53,49.2$, and $68.9 \%$ at 25,50 , and $100 \mathrm{mg} / \mathrm{kg}$ CMFPJ respectively.

We found increased expression of caspase-8, cytochrome-c, caspase-9, and caspase- 3 genes. According to the results of altered gene expression, both of the extrinsic pathway and the intrinsic pathway are the probable pathways through which CMFPJ induced apoptosis in EAC cell. Usually, due to ligand binding to exact receptors, the death-inducing signalling complex (DISC) forms and activates caspase- 8 in the extrinsic pathway (25). In the intrinsic pathway, mitochondria discharge cytochrome-c which participate in the formation of apoptosome and lead to caspase-9 activation (25). The activated caspase- 8 either directly cleaves effector caspase or cleaves Bid which finally provoke mitochondria to release cytochrome-c (25). Then cytochrome-c participates in apoptosome formation with the accumulation of procaspase-9 and apoptotic protease activating factor 1 (APAF1) to activate caspase-9 (25). Subsequently, caspase- 8 and caspase- 9 induce activation of downstream caspase-3 (25), the key effector in apoptosis which acts by constrained proteolysis of the structural proteins, including cytokeratins, PARP, and nuclear protein NuMA, and leads to apoptosis (16).

However, the inhibition of EAC growth and alteration of caspase pathways possibly were due to the combinatorial effect of lectin, flavonoids, and polyphenols of CMFPJ.

\section{ACKNOWLEDGMENTS}

We are thankful to Mr. Ruhul Amin [Senior Scientific Officer, Bangladesh Council of Scientific and Industrial Research (BCSIR), Rajshahi Division, Rajshahi, Bangladesh] as he gave us an opportunity to measure RNA quantity in his laboratory.

\section{CONFLICT OF INTEREST}

The authors have no conflict of interest.

Received October 29, 2018; Revised December 9, 2018; Accepted January 29, 2019

\section{REFERENCES}

1. Evan, G.I. and Vousden, K.H. (2001) Proliferation, cell cycle and apoptosis in cancer. Nature, 411, 342-348.

2. Kim, S.H. and Choi, K.C. (2013) Anti-cancer effect and underlying mechanism(s) of kaempferol, a phytoestrogen, on the regulation of apoptosis in diverse cancer cell models. Toxicol. Res., 29, 229-234.

3. Fingrut, O. and Flescher, E. (2002) Plant stress hormones suppress the proliferation and induce apoptosis in human cancer cells. Leukemia, 16, 608-616.

4. Elmore, S. (2007) Apoptosis: a review of programmed cell death. Toxicol. Pathol., 35, 495-516.
5. Thornberry, N.A. and Lazebnik, Y. (1998) Caspases: enemies within. Science, 281, 1312-1316.

6. Dreyer, D.L. and Huey, P.F. (1973) Coumarins of Citrus macroptera. Phytochemistry, 12, 3011-3013.

7. Abbott, I.A., Leakey, R.R. and Elevitch, C.R. (2006) Traditional Trees of Pacific Islands: Their Culture, Environment, and Use (1st edition), Permanent Agriculture Resources, Holualoa, Hawaii, USA, pp. 283-317.

8. Paul, S., Islam, M., Tanvir, E.M., Ahmed, R., Das, S., Rumpa, N.E., Hossen, M.S., Parvez, M., Gan, S.H. and Khalil, M.I. (2016) Satkara (Citrus macroptera) fruit protects against acetaminophen-induced hepatorenal toxicity in rats. Evid. Based Complement. Alternat. Med., 2016, 9470954.

9. Malik, S.K. and Chaudhury, R. (2006) The cryopreservation of embryonic axes of two wild and endangered Citrus species. Plant Genet. Resourc., 4, 204-209.

10. Rahmatullah, M., Khatun, M.A., Morshed, N., Neogi, P.K., Khan, S.U.A., Hossan, S., Mahal, M.J. and Jahan, R. (2010) A randomized survey of medicinal plants used by folk medicinal healers of Sylhet Division, Bangladesh. Adv. Nat. Appl. Sci., 4, 52-62.

11. Uddin, N., Hasan, M.R., Hossain, M.M., Hasan, M.M., Roy, A., Islam, T., Hossain, M.M., Faruque, A. and Rana, M.S. (2014) Antioxidant, brine shrimp lethality and antimicrobial activities of methanol and ethyl-acetate extracts of Citrus macroptera Montr. fruit using in vitro assay models. $B r . J$. Pharm. Res., 4, 1725-1738.

12. Paul, S., Hossen, M.S., Tanvir, E.M., Islam, M.A., Afroz, R., Ahmmed, I., Saha, M., Gan, S.H. and Khalil, M.I. (2015) Antioxidant properties of Citrus macroptera fruit and its in vivo effects on the liver, kidney and pancreas in wistar rats. Int. J. Pharmacol., 11, 899-909.

13. Sala, A., Recio, M.D.C., Giner, R.M., Máñez, S., Tournier, H., Schinella, G. and Ríos, J.L. (2002) Anti-inflammatory and antioxidant properties of Helichrysum italicum. J. Pharm. Pharmacol., 54, 365-371.

14. Hyun, J.H., Kang, J.I., Kim, S.C., Kim, E., Kang, J.H., Kwon, J.M., Park, D.B., Lee, Y.J., Yoo, E.S. and Kang, H.K. (2008) The effects of Crinum asiaticum on the apoptosis induction and the reversal of multidrug resistance in HL-60/ MX2. Toxicol. Res., 24, 29-36.

15. Correia, M.T. and Coelho, L.C. (1995) Purification of a glucose/mannose specific lectin, isoform 1, from seeds of Cratylia mollis mart. (Camaratu bean). Appl. Biochem. Biotechnol., 55, 261-273.

16. Al-Mamun, M.A., Husna, J., Khatun, M., Hasan, R., Kamruzzaman, M., Hoque, K.M., Reza, M.A. and Ferdousi, Z. (2016) Assessment of antioxidant, anticancer and antimicrobial activity of two vegetable species of Amaranthus in Bangladesh. BMC Complement. Altern. Med., 16, 157.

17. Alam, A.K., Hossain, A.S., Khan, M.A., Kabir, S.R., Reza, M.A., Rahman, M.M., Islam, M.S., Rahman, M.A.A., Rashid, M. and Sadik, M.G. (2016) The antioxidative fraction of white mulberry induces apoptosis through regulation of p53 and NFKB in EAC cells. PLOS ONE, 11, e0167536.

18. Sa, D.J., Lee, E.J. and Yoo, B.S. (2009) Apoptosis induction by menadione in human promyelocytic leukemia HL-60 cells. Toxicol. Res., 25, 113-118.

19. Lam, S.K. and Ng, T.B. (2011) Lectins: production and prac- 
tical applications. Appl. Microbiol. Biotechnol., 89, 45-55.

20. Zhang, Z.T., Peng, H., Li, C.Y., Liu, J.J., Zhou, T.T., Yan, Y.F., Li, Y. and Bao, J.K. (2010) Polygonatum cyrtonema lectin induces murine fibrosarcoma L929 cell apoptosis via a caspase-dependent pathway as compared to Ophiopogon japonicus lectin. Phytomedicine, 18, 25-31.

21. De Mejía, E.G. and Prisecaru, V.I. (2005) Lectins as bioactive plant proteins: a potential in cancer treatment. Crit. Rev. Food Sci. Nutr., 45, 425-445.

22. Kabir, S.R., Nabi, M.M., Haque, A., Zaman, R.U., Mahmud, Z.H. and Reza, M.A. (2013) Pea lectin inhibits growth of Ehrlich ascites carcinoma cells by inducing apoptosis and $\mathrm{G} 2 / \mathrm{M}$ cell cycle arrest in vivo in mice. Phytomedicine, 20, 1288-1296.
23. Islam, S., Nasrin, S., Khan, M.A., Hossain, A.S., Islam, F., Khandokhar, P., Mollah, M.N., Rashid, M., Sadik, G., Rahman, M.A. and Alam, A.H. (2013) Evaluation of antioxidant and anticancer properties of the seed extracts of Syzygium fruticosum Roxb. growing in Rajshahi, Bangladesh. BMC Complement. Altern. Med., 13, 142.

24. Pai, K.S.R., Srilatha, P., Suryakant, K., Setty, M.M., Nayak, P.G., Rao, C.M. and Baliga, M.S. (2012) Anticancer activity of Berberis aristata in Ehrlich ascites carcinoma-bearing mice: a preliminary study. Pharm. Biol., 50, 270-277.

25. Favaloro, B., Allocati, N., Graziano, V., Di Ilio, C. and De Laurenzi, V. (2012) Role of apoptosis in disease. Aging (Albany NY), 4, 330-349. 